\title{
A CASE OF CREUTZFELDT-JAKOB DISEASE THAT STARTED WITH PSYCHIATRIC SYMPTOMS
}

\author{
Hamza ŞAHİN, Deniz TUNCEL, Songül BAVLİ, Muhammet Yusuf USLUSOY
}

\author{
Kahramanmaraş Sütçü İmam University Faculty of Medicine, Department of Neurology, \\ Kahramanmaraş, TURKEY
}

\begin{abstract}
Creutzfeldt-Jakob Disease (CJD) is the most common form of human prion diseases, which cause neurodegeneration and result in death in a short time. The mortality rate reaches $85 \%$ per annum. The prevalence of CJD is very low at 1-1.6 per million. Clinical findings are in the form of rapidly progressing dementia, myoclonus, and cerebellar, pyramidal and extrapyramidal symptoms. Typically, CJD is characterised by electroencephalography (EEG) and magnetic resonance imaging (MRI) findings and 14-3-3 protein analysis positivity in the cerebrospinal fluid (CSF). Definitive diagnosis is made from histopathological examination. The purpose of this report is to emphasize the fact that $\mathrm{CJH}$ can be manifested with different psychiatric symptoms and can be misdiagnosed initially.
\end{abstract}

Keywords: Creutzfeldt-Jakob disease, psychiatric symptoms, electroencephalography, magnetic resonance imaging.

\section{PSIKIYYATRİK SEMPTOMLARLA BAŞLAYAN BİR CREUTZFELDT-JAKOB HASTALIĞI OLGUSU}

\section{ÖZET}

Creutzfeldt-Jakob hastalığı (CJH), nörodejenerasyona neden olan ve sonuçta çok kısa sürede ölümle sonuçlanan insan prion hastalıklarının en yaygın şeklidir. Ölüm oranı bir yılda \% 85'e ulaşmaktadır. CJH'nın prevelansı çok düşük olup milyonda 1-1.6'dır. Klinik bulgular hızla ilerleyen demans, miyoklonus, serebellar, piramidal ve ekstrapiramidal semptomlar șeklindedir. CJH tipik elektroensefalografi (EEG) ve manyetik rezonans görüntüleme (MRI) bulguları ve BOS'ta 14-3-3 protein analizinin pozitif olması ile karakterizedir. Kesin tan histopatolojik inceleme ile konur. Bu olguda, farklı psikiyatrik semptomlarla başvuran sporadik $\mathrm{CJH}$ 'nın nadir bir klinik prezentasyonunu sunduk. Bu raporun amacı, CJH'nın farklı psikiyatrik belirtilerle ortaya çıkabileceği ve başlangıçta yanlış teşhis edilebileceği gerçeğini vurgulamaktır. Anahtar Sözcükler: Creutzfeldt-Jakob hastalı̆̆, psikiyatrik semptomlar, elektroensefalografi, manyetik rezonans görüntüleme.

\section{INTRODUCTION}

Creutzfeldt-Jakob disease (CJD) is the most frequently seen type of human prion diseases with an annual incidence of 1 per million. Clinically the disease emerges with a rapidly progressing dementia table and is seen mostly in the fifth and sixth decades of life and more rarely in young adults. Males and females are affected at equal rates. There are 4 types of CJD; sporadic, genetic, iatrogenic and variant. In $85 \%$ of cases, the disease occurs in the sporadic form.
Following the onset of symptoms, mean life expectancy is up to 1 year. In the early stages of CJD, depressive symptoms such as fatigue, apathy, withdrawal, sleep and eating disorders and personality changes may be seen in approximately 1 in 3 patients (1-4).

The aim of this paper was to present a case of sporadic CJD who presented with behavioural and mood changes and paranoid thoughts in the initial period.

Corresponding author: Hamza Şahin MD. Kahramanmaraş Sütçü İmam University Faculty of Medicine, Department of Neurology, Kahramanmaraş, Turkey. Phone: +903442212337 E-mail: hamzasahin85@hotmail.com Received: $18.06 .2018 \quad$ Accepted: 17.07.2018

This article should be cited as following: Şahin H, Tuncel D, Bavlı S, Uslusoy M.Y. A case of Creutzfeldt-Jakob disease that started with psychiatric symptoms. Turkish Journal of Cerebrovascular Diseases 2018; 24 (3): 128-131. doi:10.5505/tbdhd.2018.02170 


\section{CASE}

A 57-year old female patient presented with complaints that had started a month previously of aggressive behaviour, swearing, unexplained crying and laughing and loss of appetite. The patient had started to say things which had not happened, to see ghosts and had developed a fear that she would be killed. The patient's family had taken her to another centre, where she had been given a prescription for anti-depressants. With the addition of complaints of lack of balance, inability to walk and sudden twitching of the hands, the family brought the patient to our hospital as an emergency. In the neurological examination, the patient was conscious, had impaired personspace-time orientation and was partially cooperative. The motor and cranial system examination was normal, deep tendon reflexes were normoactive and the Babinski sign was evaluated as bilateral positive and neck stiffness was negative.

The patient had a history of diabetes and myocardial infarct. In the laboratoryy examination, blood glucose was determined as $210 \mathrm{mg} / \mathrm{dl}$. Other biochemical values, thyroid function tests, brucella, salmonella and syphilis tests, vasculitis markers, tumour markers, serum ammoniac level, hemogram, blood gas values, pulmonary radiograph and ECG findings were normal. The biochemical, serological (brucella, acid-resistant bacteria staining, herpes simplex virus polymerase chain reaction) and cytological evaluations of CSF were found to be normal. No bacteria were observed in the gram staining of CSF. The CSF 143-3 protein examination was determined to be positive.

Widespread theta wave activity and periodically recurring sharp slow wave activity was determined on EEG. On MRI examination, foci were determined as isointense on T1A sequences and hyperintense on T2 and FLAIR sequences in various localisationsin the bilateral corona radiata and centrum semi-ovale. On brain diffusion MRI, bilateral symmetrical diffusion restriction at the level of basal ganglions bilaterally and hyperintense areas in the cerebral cortex were observed (Figure I). On EEG, generalised or lateralised periodic sharp wave activity was determined and suppression with intravenous diazem (Figure II). The patient was admitted to our clinic with a pre-diagnosis of encephalitis and empirical treatment was started of aciclovir $(30 \mathrm{mg} / \mathrm{kg})$, ceftriaxon $(2 \times 2 \mathrm{mg})$ and levatiracetam $(3000 \mathrm{mg} /$ day). Following other tests, a diagnosis was made of sporadic type CJD. In follow-up in the Intensive Care Unit, clinical deterioration was observed to continue and the patient was exitus on the 45th day after admission.

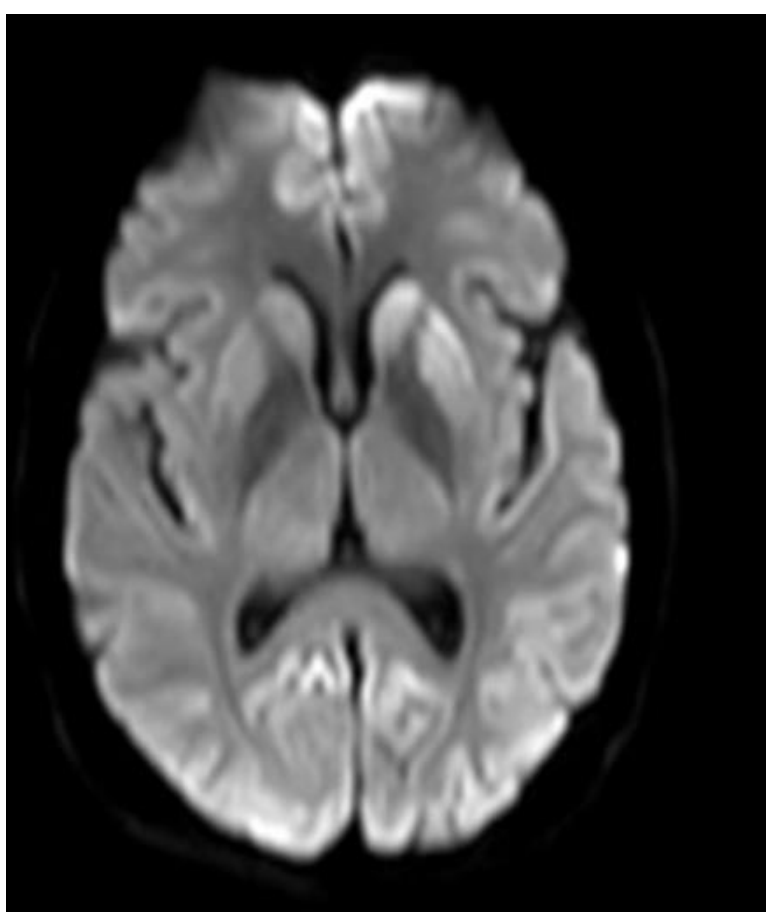

Figure I. Bilateral symmetrical diffusion restriction at the level of basal ganglia on both sides and hyperintense areas in the cerebral cortex.

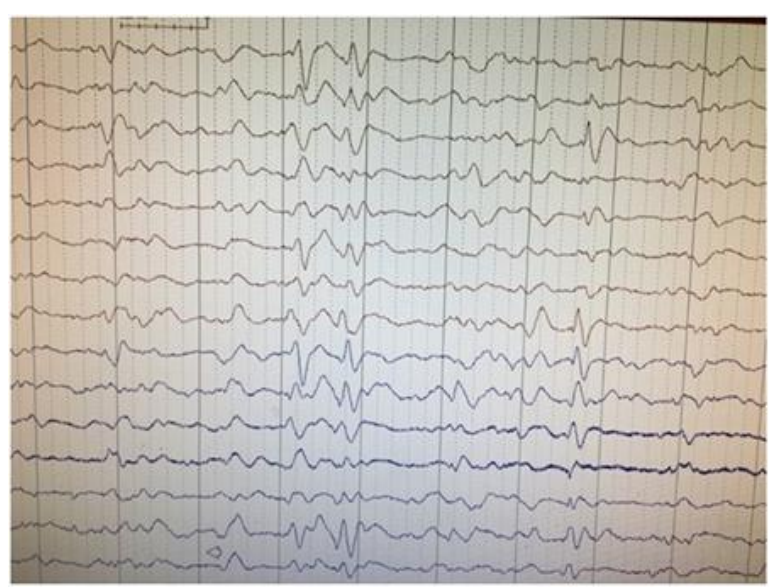

Figure II. Periodic sharp wave activity on generalized or lateralized EEG. 


\section{DISCUSSION}

Creutzfeldt-Jakob disease, which is a neurodegenerative disease with a fatal course, is the most frequently seen type of spongiform encephalopathies. There are 4 types of CJD, as sporadic, familial, iatrogenic and variant. Familial prion diseases develop associated with autosomal dominant transmission pathogenic mutations in the PrP gene (PRNP) which is encoded in the 20th chromosome and constitutes approximately 10\% of human prion diseases. Familial CJD generally has early age onset and the course is longer. While typical EEG findings are not usually seen, approximately 20 gene mutations have been shown in genetic examinations $(5,6,7)$.

Iatrogenic causes include dura mater graft implantation, corneal transplantation, contaminated EEG electrode implantation, surgical operations performed with contaminated instruments and growth hormone treatments of hypophysis gland origin. The disease course, duration and neuropathologyof iatrogenic type CJD are similar to the sporadic type (8). Dry and variant CJD are acquired prion diseases of dietary origin transmission. This disease progresses more slowly than the sporadic form with dementia and EEG findings forming within mean 14 months. In the variant form, typical EEG findings and myoclonus are seen at a lower rate than in the sporadic form.

Life expectancy in these patients may extend up to 10 years $(9,10)$. In classic sporadic CJD, the clinical table is highly variable and many cases start as subacute. Generally, a rapidly progressing dementia table is accompanied by widespread myoclonus and pyramidal, extra-pyramidal, cerebellar, psychiatric or visual findings. Clinical findings progress within weeks and akinetic mutism develops. $70 \%$ of patients are lost before 6 months. In a third of patients, there are prodromal symptoms including pain sensations that cannot be well-defined, weight loss, depression, insomnia, headache, listlessness and fatigue. EEG is one of the most important examinations and has been reported to have up to $95 \%$ diagnostic value. In addition to a slowing of the base rhythm, the presence of widespread, morphological triphasic periodic sharp wave discharges is a significant finding. Protein 14-3-3 in CSF has been reported to have 94\%-95 sensitivity and 84\%-93\% specificity. Cerebral atrophy, and an increase in signal density in the putamen, caudate nucleus and cerebral cortex are MRI findings that can be determined in CJD. While the sensitivity of T2-weighted and proton density MRI examinations is lower (67\%79\%), FLAIR and diffusion-weighted examinations have been reported to have high sensitivity. Although definitive diagnosis is made from brain biopsy, this is not always an easy method to apply $(1,11,12)$.

In the current case, the age of the patient, and the progression within a month of behavioural changes, cognitive deterioration and cerebellar symptoms, together with the typical findings on EEG and cranial MRI directed the diagnosis to CJD. The positivity of 14-3-3 in CSF supported the diagnosis of CJD in this patient. As there was no family history, no risk factors for variant CJD, and because of the clinical course characteristics, the MRI findings and elevated 14-3-3, the diagnosis of sporadic CJD was made.

As in the current case, CJD may start with neuropsychiatric symptoms. It has been reported that $10 \%$ of cases first present with psychiatric symptoms such as depression and personality changes, which are determined in the early stage of one in three cases $(13,14)$. This case is interesting as it is a case of sporadic CJD that started with psychiatric symptoms. As complaints of unease and behavioural changes were initially predominant, the patient was started on antidepressant treatment at another centre. With the subsequent progression of the disease and increase in neurological symptoms, investigations were made in more detail and a diagnosis of sporadic CJD was made.

In conclusion, in patients with personality changes and psychiatric symptoms with the addition of neurological symptoms during followup and when rapidly progressing dementia findings are determined, CJD must be considered in the differential diagnosis.

\section{REFERENCES}

1. İnanç $Y$, Arlıer Z, İnanç $Y$, Geyik S, Giray S, Kocatürk Ö. Creutzfeldt-Jakob disease presenting with dizziness, fatigue and neuropsychiatric symptoms: two case reports.Gaziantep Med J 2015;21(2):142-146.

2. Kurne A, Ertuğrul A, Yağcıoğlu EA, Demirci E, Yazıcı KM, Kansu T. Creutzfeldt-Jakob Disease: A Case That Started with Psychiatric Symptoms. Turkish Psychiatry Journal 2005; 16(1):55-59.

3. Johnson RT. Prion diseases. Lancet Neurol 2005; 4: 635642. 
Şahin et al.

4. Hill AF, Joiner S, Wadsworth JDF, Sidle KCL, Bell JE, Budka $\mathrm{H}$, Ironside JW, Collinge J. Molecular classification of sporadic Creutzfeldt Jakob disease. Brain 2003; 126: 1333 1346.

5. Wadsworth JDF, Hill AF, Beck JA, Collinge J. Molecular and clinical classification of human prion disease. Br Med Bull 2003; 66: 241-254.

6. Güven H, Çomoğlu S, Yaman S. Possible Creutzfeldt-Jakob Disease. Turkish Journal of Geriatrics 2006; 9 (3): 182-187.

7. Renard D, Orgeval J, Sazdovitch V, Seilhean D, Thouvenot E. Genetic Creutzfeldt-Jakob disease with an 8-year disease course. Acta neurologica Belgica 2018: 118(2): 313.

8. Brown $\mathrm{P}$; Infections of the nervous system. In: Butterworth- Heinemann, Philadelphia. Bradley WG, Daroff RB, Fenichel GM, Marsden CD; Neurology in Clinical Practice 2000:1424-1429.

9. Brown P, Will RG, Bradley R, Asher DM, Detwiler L;Bovine spongi form encephalopathy and variant Creutzfeldt- Jacob disease: Background, evolution, and curren tconcerns. Emerg Infect Dis 2001; 7: 6-16.
10. Demir N, Mutluay B, Öztürk M, Altunkaynak Y, Sözmen V, Küçükoğlu H, Dirican A, Baybaş S. Sporadic CreutzfeldtJacob Disease: 5 Case Reports. Cerrahpaşa Medical Journal 2006; 37: $58-63$

11. Brown K, Mastrianni JA.The prion diseases. J Geriatr Psychiatry Neurol. 2010; 23(4):277-98.

12. Torres Herrán GE, Ortega Herrera AD, Burbano BM, Serrano-Dueñas M, Ortiz Yepez MA, Barrera Madera RA, Masabanda Campaña LA, Baño Jiménez GD, Santos Saltos DM, Correa Díaz EP. Case series of Creutzfeldt-Jakob disease in a third-level hospital in Quito. BMC Neurol. 2018; 18 (1): 55.

13. Brown P, Cathala F, Castaigne P ve ark. Creutzfeldt-Jacob disease: clinical analysis of a consecutive series of 230 neuropathologically verified cases. Ann Neurol 1986; 20: 597-602.

14. Dervaux A, Laine $H$ The psychiatric forms of CreutzfeldtJakob disease. Presse Med 2003; 32:1466-1468. 